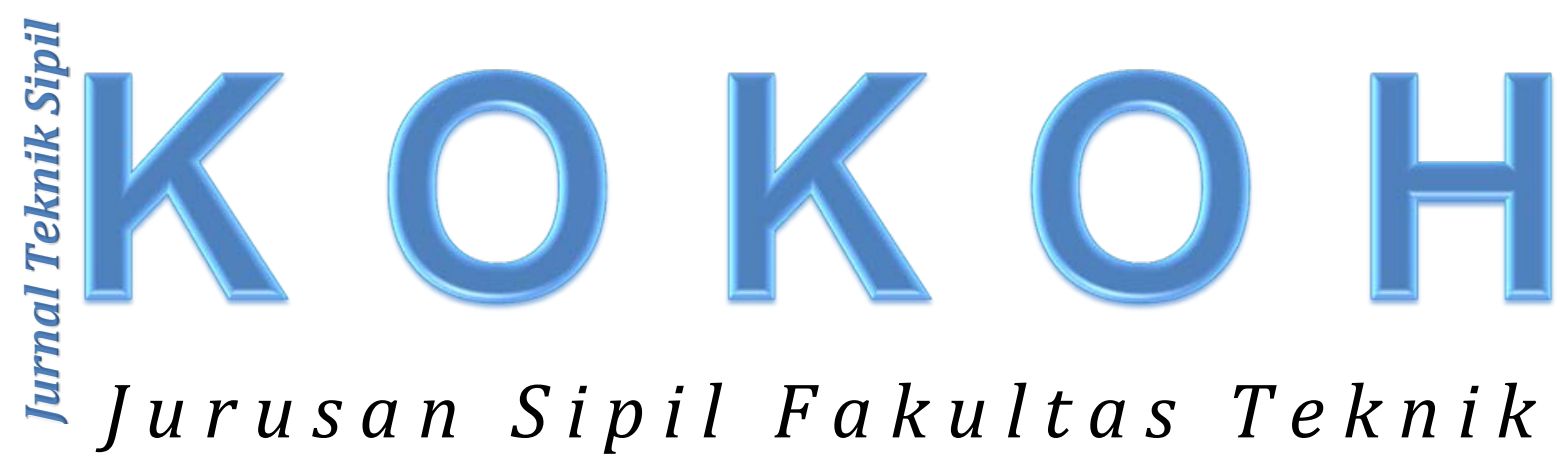

Volume 12 No. 1

April 2011

ISSN : $1411-3864$

Pengaruh Temperatur Tinggi Terhadap Kuat Tekan

Dan Kuat Tarik Beton

(Syahrul Sariman)

Perencanaan Sistem Drainase Kecamatan Towuti Kabupaten Luwu Timur

(Amiruddin Rana)

Studi Penerapan Keselamatan dan Kesehatan Kerja (K3) pada Proyek Pekerjaan Jalan Maros - Pangkep

(Muh. Yusuf Nur)

Pengaruh Penggunaan Material Pasir Putih Baranti Terhadap Kekuatan Beton (Arman Setiawan)

Penambahan Bubuk Bata Merah Terhadap Parameter Kekuatan Tanah Lempung (Tamrin Mallawangeng)

Analisis Sistem Pengelolaan dan Kebutuhan Air Bersih Terhadap Pengembangan Wilayah Kota Masohi Kabupaten Maluku Tengah

(Satriawati Cangara)

Yayasan Andi Sose

Universitas "45" Makassar 


\title{
STUDI PENGARUH PENGGUNAAN MATERIAL PASIR PUTIH BARANTI TERHADAP KEKUATAN BETON
}

\author{
Oleh : Arman Setiawan ${ }^{1)}$
}

\begin{abstract}
In Indonesia, especially South Sulawesi fine aggregate (sand) which is used to mix concrete comes from the river, and a blackish brown color brown. Is still lacking or rarely use white sand for concrete mix, because it usually comes from the beach and contains a high salt content.

This study aims to determine how the quality / value characteristics of white sand and concrete compressive strength $\left(f^{\prime} c\right)$ generated by using white sand, and how it compares with the compressive strength using regular sand. The process of data retrieval is done by testing the aggregate characteristics in the laboratory, making the test object, and the concrete compression test at 28 days.

The results showed the quality / value characteristics of white sand in general qualified, concrete compressive strength $\left(f^{\prime} c\right)$ using white sands of 23.54 MPa and a tensile strength average - average of $3.28 \mathrm{MPa}$ while using common sand concrete compressive strength $\left(f^{\prime} c\right)$ gained 22.19 $\mathrm{MPa}$ and tensile strength average - average at $3.11 \mathrm{MPa}$, these results indicate that the compressive strength of concrete by using white sand is higher than using regular sand.
\end{abstract}

\section{Keyword : fine aggregate, mix concrete, compressive strength}

\section{PENDAHULUAN}

Sampai saat ini beton masih menjadi pilihan utama dalam pembuatan struktur, karena kemudahan untuk mendapatkan material penyusunnya. " Sebagian besar bahan untuk membuat beton adalah bahan lokal kecuali semen portland atau bahan tambah kimia. Bahan lokal yang dimaksud adalah agregat dan air. Secara umum, agregat dapat dibedakan berdasarkan ukurannya yaitu agregat kasar dan agregat halus. Di Indonesia, khususnya Sulawesi Selatan agregat halus ( pasir ) yang biasa digunakan untuk campuran beton berasal dari sungai, dan berwarna coklat kehitam - hitaman. Sampai saat ini masih kurang atau jarang yang menggunakan pasir yang berwarna putih untuk campuran beton, karena

\footnotetext{
${ }^{1)}$ Dosen Teknik Sipil Universitas 45 Makassar
} 
biasanya berasal dari pantai dan mengandung kadar garam yang tinggi. Kadar garam yang tinggi menyebabkan pasir banyak menyerap air dari udara sehingga kondisi pasir akan selalu basah atau agak basah yang tidak dikehendaki dalam pengerjaan beton. Pasir ini juga menyebabkan terjadinya pengembangan ketika beton sudah jadi. Sehingga untuk digunakan sebagai campuran beton harus diberikan perlakuan khusus.

Di Kabupaten Sidenreng Rappang ( Sidrap ) tepatnya Kecamatan Baranti Dusun Kessi Pute terdapat penambangan pasir putih, penambangan tersebut dilakukan oleh masyarakat setempat dengan menggunakan mesin pompa air, pasir putih tersebut berasal dari dalam tanah. Jika dilihat dari permukaan tanah di daerah ini, volume pasir putih cukup banyak karena sawah, kebun dan halaman rumah warga setempat dipenuhi pasir putih. Masyarakat setempat masih kurang yang menggunakan pasir putih tersebut sebagai bahan campuran beton. Hal ini dipengaruhi oleh kurangnya pengetahuan masyarakat tentang sifat karakteristik pasir putih yang dapat mempengaruhi kualitas beton, dan bagaimana nilai kuat tekan yang dapat dihasilkan dibanding dengan pasir biasa dan juga karena seringnya menggunakan pasir biasa dalam pekerjaan beton.

\section{TINJAUAN PUSTAKA}

\subsection{Pengertian Beton}

Beton adalah campuran antara semen portland atau semen hidrolik yang lain, agregat halus, agregat kasar dan air, dengan atau tanpa bahan campuran tambahan membentuk massa padat" ( SK SNI T - 15 - 1990 03 ). Samekto dan Rahmadiyanto ( 2001 : 35 ), menjelaskan bahwa dalam bidang bangunan yang dimaksud dengan beton adalah "campuran dari agregat halus dan agregat kasar ( pasir, kerikil, batu pecah , atau jenis agregat lain) dengan semen, yang dipersatukan oleh air dengan perbandingan tertentu".

\subsection{Sifat-sifat Umum Beton}


Pada umumnya beton terdiri dari $\pm 15 \%$ semen, $8 \%$ air, $3 \%$ udara, selebihnya pasir dan kerikil. Campuran tersebut setelah mengeras mempunyai sifat yang berbeda - beda, tergantung pada cara pembuatannya, perbandingan campuran, cara mencampur, mengangkut, mencetak, memadatkan, merawat dan sebagainya yang akan mempengaruhi sifat - sifat beton.

\subsection{Agregat Untuk Beton}

Jumlah agregat dalam beton $\pm 75 \%$ dari volume beton itu sendiri. Meskipun fungsinya hanya sebagai pengisi, karena komposisi agregat yang cukup besar, maka kualitas agregat sangat mempengaruhi kualitas beton.

Agregat beton merupakan butiran - butiran mineral yang digunakan sebagai pembentuk beton dan semen sebagai pengikatnya. Jenis agregat dapat dibedakan menurut asal perolehannya, berat jenis, bentuk serta besar butiran.

\subsubsection{Jenis agregat ditinjau dari asalnya}

\section{a. Agregat Alam}

Agregat alam adalah agregat yang langsung di peroleh dari alam maupun melalui proses penghancurannya. Agregat alami dapat diklasifikasikan ke dalam sejarah terbentuknya peristiwa geologi, yaitu agregat beku, agregat sedimen, dan agregat metamorf, yang kemudian dibagi lagi menjadi kelompok - kelompok yang lebih kecil. Pasir alam terbentuk dari pecahan batu karena beberapa sebab, pasir alam dapat diperoleh dari dalam tanah, pada dasar sungai, atau dari tepi laut. Oleh karena itu pasir alam dapat digolongkan menjadi 3 macam :

(1) Pasir galian. Pasir golongan ini diperoleh langsung dari permukaan tanah dengan cara menggali terlebih dahulu. Pasir ini biasanya tajam, bersudut, berpori, dan bebas dari kandungan garam 
(2) Pasir sungai. Pasir ini diperoleh langsung dari dasar sungai, yang pada umumnya berbutir halus dan bulat - bulat akibat proses gesekan. Pada sungai tertentu yang dekat dengan hutan kadang kadang banyak mengandung humus.

(3) Pasir pantai. Pasir pantai ialah pasir yang diambil dari pantai. Pasir pantai berasal dari hasil gerusan air di dasar laut yang terbawa arus air laut dan mengendap di pantai. Pasir pantai biasanya berbutir halus. Bila merupakan pasir dari dasar laut maka pasirnya banyak mengandung garam. Oleh karena itu maka pasir pantai diperiksa dulu sebelum dipakai

b. Agregat Buatan

Agregat buatan biasanya digunakan untuk tujuan tertentu atau karena kekurangan agregat batuan - batuan alam. Agregat buatan yang umum dibuat adalah batu pecah, pecahan bata/genteng yang bersih, agregat ringan seperti hydite yang terbuat dari tanah liat. Agregat pecahan batu diperoleh dengan memecahkan batu menjadi butiran sebesar yang diingini dengan cara meledakkan, memecahkan, dan mengayak.

\subsubsection{Jenis Agregat ditinjau dari Berat Jenisnya}

\section{a. Agregat Ringan}

Agregat ringan yaitu agregat yang memiliki berat jenis kurang dari $2.0 \mathrm{~kg} / \mathrm{m}^{3}$ dan biasanya digunakan pada beton non structural.

b. Agregat Normal

Agregat Normal yaitu agregat yang memiliki berat jenis lebih dari 2.5 $\mathrm{kg} / \mathrm{m}^{3}$ sampai $2.7 \mathrm{~kg} / \mathrm{m}^{3}$. biasanya berasal dari kuarsa, basalt dan sebagainya.

c. Agregat Berat

Agregat berat yaitu agregat yang memiliki berat jenis lebih dari 2.8 $\mathrm{kg} / \mathrm{m}^{3}$. Misalnya magnetic atau serbuk besi. 


\subsubsection{Jenis Agregat menurut Besar Butiran}

a. Agregat Halus, adalah agregat yang semua butirannya menembus ayakan dengan lubang $4,8 \mathrm{~mm}$.

b. Agregat Kasar, adalah agregat dengan butiran - butiran tertinggal di atas ayakan dengan lubang 4,8 mm, tetapi lolos ayakan $40 \mathrm{~mm}$.

c. Batu, adalah agregat yang besar butirannya lebih dari $40 \mathrm{~mm}$.

\subsection{Material Beton}

Secara umum, yang berpengaruh terhadap kuat tekan beton adalah material dari pada beton itu sendiri, material beton itu adalah sebagai berikut :

\subsubsection{Semen}

Semen portland atau biasa disebut semen adalah bahan pengikat hidrolis berupa bubuk halus yang dihasilkan dengan cara menghaluskan klinker dengan batu gips sebagai bahan tambahan. Semen merupakan bahan campuran yang secara kimiawi aktif setelah berhubungan dengan air, agregat tidak mempunyai peranan yang penting dalam reaksi kimia tersebut tetapi berfungsi sebagai bahan pengisi.

\subsubsection{Agregat Halus}

Agregat halus yang digunakan untuk campuran beton harus terdiri dari butir - butir yang tajam dan keras, bersifat kekal yang tidak mudah hancur atau pecah oleh pengaruh cuaca, seperti terik matahari dan hujan. Kadar lumpur yang terkandung dalam agregat halus tidak boleh lebih dari $6 \%$, bila kadar lumpur melampaui $6 \%$ maka agregat harus dicuci, kadar organis yang terlalu banyak yang terkandung dalam agregat halus akan mempengaruhi kualitas beton, hal ini terjadi karena bahan - bahan kimia akan bereaksi dengan komponen - komponen tertentu dari pasta semen yang telah mengeras, untuk mencegah hal tersebut maka pada saat pengerjaan beton harus homogen dan padat. Berat jenis dan penyerapan 
agregat halus berpengaruh pada volume yang diisi oleh agregat, dan banyaknya campuran agregat dalam campuran beton, semakin tinggi nilai berat jenis agregat halus maka semakin kecil nilai penyerapannya.

Gradasi agregat halus harus terdiri dari berbagai macam ukuran, ukuran yang bervariasi dari agregat akan menghasilkan beton yang padat, karena akan saling mengisi sehingga akan diperoleh beton dengan kepadatan tinggi, mudah dikerjakan dan mudah dialirkan seperti terlihat pada gambar 2.1 .

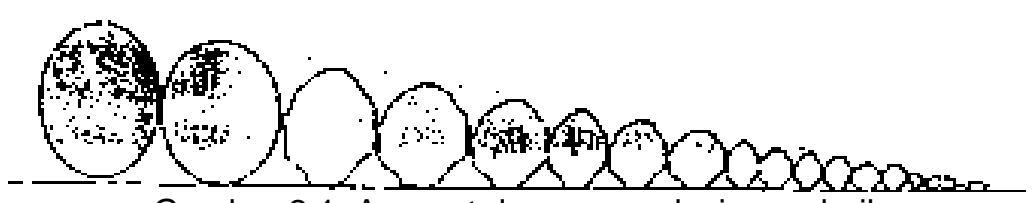

Gambar 2.1. Agregat dengan gradasi yang baik

Dibandingkan dengan gradasi yang seragam ( gambar 2.2), beton yang dihasilkan akan mudah mengalami proses segregasi. Proses segregasi terjadi akibat mudahnya partikel agregat halus naik ke permukaan karena tedapat banyak rongga - rongga terbuka dan menghasilkan kepadatan beton yang rendah,

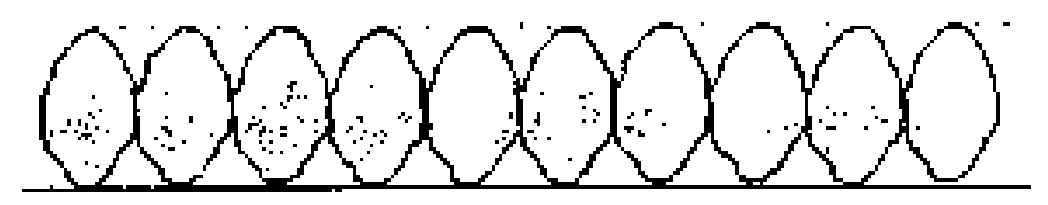

Gambar 2.2. agregat dengan gradasi yang seragam

Sedangkan untuk agregat celah ( gambar 2.3 ), beton yang dihasilkan juga kurang baik karena distribusi bahan pengikat tidak akan merata akibat sebagian pasta semen dan butiran agregat halus lainnya harus mengisi jumlah gradasi yang terputus,

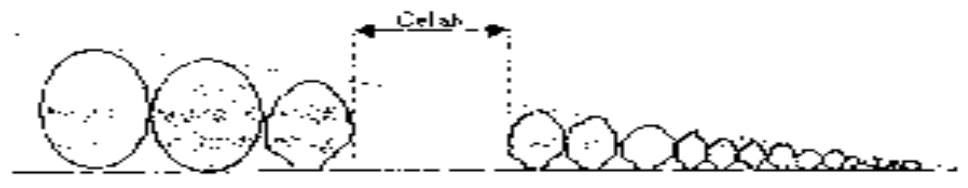

Gambar 2.3. agregat dengan gradasi yang celah

Menurut (SK-SNI T-15-1990-03) syarat gradasi untuk agregat normal : 
Tabel 2.1 Batas gradasi agregat halus

\begin{tabular}{|c|c|c|c|c||}
\hline \multirow{2}{*}{ Lubang Ayakan $(\mathrm{mm})$} & \multicolumn{4}{|c|}{ Persen Berat Butir Lewat Ayakan } \\
\cline { 2 - 5 } & $\mathrm{I}$ & $\mathrm{II}$ & $\mathrm{III}$ & IV \\
\hline 10 & 100 & 100 & 100 & 100 \\
\hline 4,8 & $90-100$ & $90-100$ & $90-100$ & $95-100$ \\
\hline 2,4 & $60-95$ & $75-100$ & $85-100$ & $95-100$ \\
\hline 1,2 & $30-70$ & $55-90$ & $75-100$ & $90-100$ \\
\hline 0,6 & $15-34$ & $35-59$ & $60-79$ & $80-100$ \\
\hline 0,3 & $5-20$ & $8-30$ & $12-40$ & $15-50$ \\
\hline 0,15 & $0-10$ & $0-10$ & $0-10$ & $0-15$ \\
\hline
\end{tabular}

(Sumber : Mulyono, 2004:91)

Keterangan : - Daerah Gradasi I = Pasir Kasar

- Daerah Gradasi II = Pasir Agak Kasar

- Daerah Gradasi III = Pasir Halus

- Daerah Gradasi IV = Pasir Agak Halus

Spesifikasi karakteristik agregat halus (pasir) dapat dilihat pada Tabel 2.2

Tabel 2.2 Spesifikasi karakteristik agregat halus

\begin{tabular}{|c|c|c|c||}
\hline No. & Karaktristik agregat halus & Interval batas & Pedoman \\
\hline 1 & Kadar lumpur, ( $\%)$ & $0,2-6$ & ASTM C117 \\
\hline 2 & Kadar organik, ( warna $)$ & $<$ No. 3 & ASTM C40 \\
\hline 3 & Kadar air, $(\%)$ & $3-5$ & ASTM C566 \\
\hline 4 & Berat volume, ( kg/ltr $)$ & $1.4-1.9$ & ASTM C29 \\
\hline 5 & Resapan, ( $\%)$ & $0.20-2.00$ & ASTM C128 \\
\hline 6 & Berat jenis spesifik & $1.60-3.20$ & ASTM C128 \\
\hline 7 & Modulus kehalusan & $2.2-3.1$ & ASTM C136 \\
\hline
\end{tabular}

\subsubsection{Agregat Kasar}

Kekuatan agregat bervariasi dalam batas yang besar. Butir-butir agregat dapat bersifat kurang kuat karena dua hal. Pertama, karena terdiri dari bahan yang lemah atau terdiri dari partikel yang kuat tetapi tidak baik dalam hal pengikatan ( interlocking ). Kedua, porositas yang besar yang akan mempengaruhi keuletan atau ketahanan terhadap beban kejut. Dalam hal pemilihan agregat kasar, porositas yang rendah merupakan faktor yang sangat menentukan untuk menghasilkan suatu adukan beton yang berkualitas baik.

Ukuran yang bervarisi dari agregat kasar sangat mempengaruhi kualitas beton ( seperti yang terlihat pada gambar 2.1 ), dibanding dengan agregat yang mempunyai ukuran yang seragam atau celah, karena 
agregat yang mempunyai variasi ukuran akan mengisi rongga - rongga yang terjadi akibat agregat yang berukuran besar. Tabel 2.3 memperlihatkan batas gradasi yang baik untuk agregat kasar.

Tabel 2.3 Syarat agregat kasar

\begin{tabular}{|c|c|c|c|}
\hline \multirow{2}{*}{$\begin{array}{c}\text { Lubang Ayakan ( } \\
\mathrm{mm})\end{array}$} & \multicolumn{3}{|c|}{ Persen Berat Butir Lewat Ayakan, Besar butir maksimum } \\
\cline { 2 - 4 } & $40 \mathrm{~mm}$ & $20 \mathrm{~mm}$ & $12,5 \mathrm{~mm}$ \\
\hline 40 & $95-100$ & 100 & 100 \\
\hline 20 & $30-70$ & $95-100$ & 100 \\
\hline 12,5 & - & - & $90-100$ \\
\hline 10 & $10-35$ & $25-55$ & $40-85$ \\
\hline 4,8 & $0-5$ & $0-10$ & $0-10$ \\
\hline
\end{tabular}

(Sumber:Tri Mulyono, 2004:94)

Spesifikasi karakteristik agregat kasar (batu pecah) dapat dilihat pada Tabel 2.4

Tabel 2.4 Spesifikasi karakteristik agregat kasar (batu pecah)

\begin{tabular}{|r|l|c|c|}
\hline No. & \multicolumn{1}{|c|}{ Karaktristik agregat kasar } & Interval batas & Pedoman \\
\hline 1 & Kadar lumpur (\%) & $0,2-1,0$ & ASTM C117 \\
\hline 2 & Kadar air (\%) & $0,5-2,0$ & ASTM C556 \\
\hline 3 & Berat volume ( kg/ltr ) & $1,6-1,9$ & ASTM C29 \\
\hline 4 & Resapan (\%) & $0,2-4,0$ & ASTM C127 \\
\hline 5 & Berat jenis spesifik & $1,6-3,2$ & ASTM C127 \\
\hline 6 & Modulus kehalusan & $5,5-8,5$ & ASTM C104 \\
\hline 7 & Keausan (\% ) & $15-50$ & ASTM C131 \\
\hline
\end{tabular}

\subsubsection{Air}

Pada pekerjaan beton, air mempunyai beberapa fungsi yaitu: pembersih agregat dari kotoran yang melekat, merupakan media untuk mencampur, mengecor dan memadatkan serta memelihara beton.

Menurut SNI-03-2847-2002 dalam pasal 5.4 ayat 1 dan 2 mensyaratkan sebagai berkut :

a. Air yang digunakan dalam campuran beton harus bersih dan bebas dari bahan-bahan yang merusak yang mengandung oli, asam, alkali, garam dan bahan organik, atau bahan-bahan lainnya yang merugikan terhadap beton atau tulangan. 
b. Air pencampur yang diguanakan pada beton prategang atau beton yang didalamnya tertanam logam aluminium, termasuk air bebas yang terkandung dalam agregat, tidak boleh mengandung ion klorida dalam jumlah yang membahayakan.

\subsection{Sifat-sifat Beton}

\subsubsection{Kuat Tekan Beton}

Kekuatan tekan beton adalah kriteria untuk menentukan kualitas beton, dimana prosedur pengukuran didasarkan pada SKSNI T - 15 1990- 03. Pembebanan pada pengujian kuat tekan termasuk pembebanan statik monotonic dengan menggunakan compressive Test. Beban yang bekerja akan terdistribusi secara continue melalui titik berat adalah :

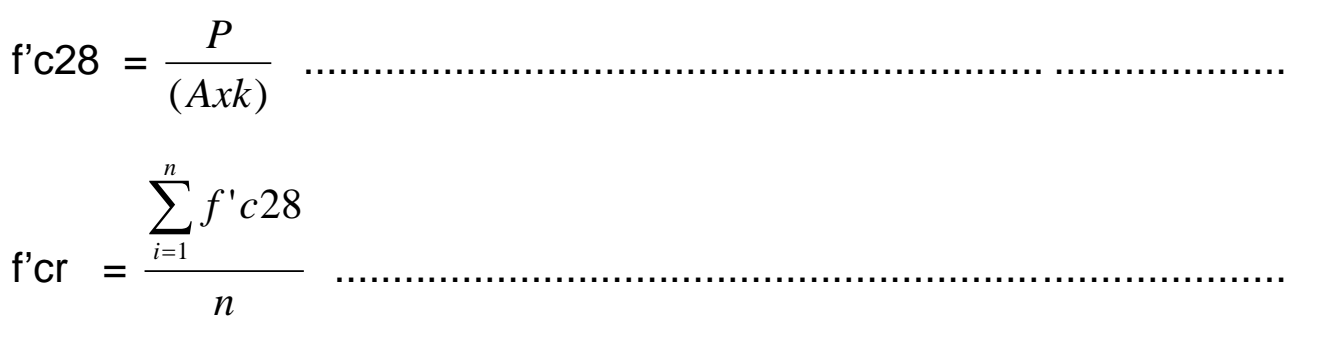

Keterangan : f'c28= kuat tekan masing - masing benda uji $\left(\mathrm{kg} / \mathrm{cm}^{2}\right)$ $\mathrm{f}^{\prime} \mathrm{cr}=$ kuat tekan rata-rata benda uji $\left(\mathrm{kg} / \mathrm{cm}^{2}\right)$

$\mathrm{k}=$ koefisien umur beton

$\mathrm{P}=$ beban maksimum $(\mathrm{kg})$

$A \quad=$ luas penampang $\left(\mathrm{cm}^{2}\right)$

$\mathrm{n} \quad=$ jumlah benda uji

Dengan menganggap bahwa hasil pengujian menyebar normal, maka deviasi standar dapat dihitung berdasarkan persamaan :

$S=\sqrt{\frac{\sum_{1}^{n}\left(f^{\prime} c 28-f^{\prime} c r\right)^{2}}{n-1}}$

$f^{\prime} \mathrm{c}=\mathrm{f}^{\prime} \mathrm{cr}-1,64 . \mathrm{S}$ 


$$
\begin{aligned}
\text { Keterangan : } \mathrm{S} & =\text { Deviasi standar }(\mathrm{MPa}) \\
\mathrm{f}^{\prime} \mathrm{C} & =\text { Kuat tekan karakteristik benda uji (MPa) } \\
\mathrm{f}^{\prime} \mathrm{cr} & =\text { Kuat tekan rata-rata benda uji (MPa) } \\
\mathrm{n} & =\text { Jumlah benda uji }
\end{aligned}
$$

Harga deviasi standar ini tergantung pada kekuatan tekan beton yang secara tidak langsung dipengaruhi oleh metode pelaksanaan atau pengecoran, dan diformulasikan menurut SK.SNI T-15-1990-03.

Bila suatu produksi beton tidak mempunyai data hasil uji yang cukup (sedikitnya 30 buah), maka nilai deviasi standar adalah perkalian deviasi standar yang dihitung dari data hasil uji dengan faktor pengali.

Tabel 2.5 Faktor pengali deviasi standar

\begin{tabular}{|c|c|}
\hline Jumlah Pengujian & Faktor pengali deviasi standar \\
\hline 15 & 1.16 \\
\hline 20 & 1.08 \\
\hline 25 & 1.03 \\
\hline 30 atau lebih & 1.00 \\
\hline
\end{tabular}

(Sumber : Tri Mulyono, 2004:182)

\subsubsection{Kuat Tarik Belah Beton}

Pengamatan kuat tarik beton khususnya pada beton bertulang sangat penting pada penentuan kemungkinan pencegahan keretakan akibat susut dan perubahan panas. Sedang untuk beton tidak bertulang, hasil pengujian ini dimanfaatkan dalam perencanaan konstruksi jalan raya dan lapangan terbang serta untuk beton prategang. Pada pembangunan jalan dan landasan pacu pesawat terbang ( runway), kekuatan tarik mempunyai arti yang sangat penting. Sebagai contoh, tekanan lentur atau modulus kehancuran ( modulus of rupture) atau kekuatan tarik pada komponen yang memikul beban lentur sangat berguna untuk mendistribusikan beban terpusat yang diterima dari roda kendaraan terhadap keseluruhan luas lantai perkerasan atau runway. Selain itu, beton juga tetap harus dapat bertahan terhadap tegangan tarik akibat 
proses pengeringan atau perbedaan temperatur sepanjang usia pakainya.

Kuat tarik beton berkisar seper-delapan belas kuat desak pada waktu umurnya masih muda, dan berkisar seper-dua puluh sesudahnya. Biasanya tak diperhitungkan di dalam perencanaan bangunan beton. Kuat tarik merupakan bagian penting di dalam menahan retak-retak akibat perubahan kadar air dan suhu. Pengujian kuat tarik diadakan untuk pembuatan beton konstruksi jalan raya dan lapangan terbang.

\subsection{Pasir Putih}

Pasir putih pada umumnya berasal dari pantai, namun di kecamatan Baranti Kabupaten Sidenreng Rappang tepatnya di dusun Kessi Pute terdapat pasir putih daratan. Berbeda dengan daerah - daerah lain, hampir semua wilayah dusun Kessi Pute di penuhi pasir putih, misalnya halaman rumah, kebun, dan sawah penduduk setempat. Hal ini mempengaruhi hasil pertanian di wilayah tersebut, misalnya tanaman padi yang sulit untuk tumbuh dengan normal atau berbuah sehingga mempengaruhi hasil panen penduduk di daerah ini.

Beberapa warga di daerah ini memanfaatkan lahan mereka dengan melakukan penambangan pasir putih yang kemudian di jual, penambangan di lakukan dengan menggunakan mesin pompa air, pasir putih di pompa dari dalam tanah yang terbawa bersama air kemudian di saring sehingga terpisah dengan air, lumpur dan tanah. Setelah dilakukan penyaringan pasir putih ini kemudian di simpan di dalam karung.

Pasir putih ini mempunyai butiran yang agak kasar dan jika terkena sinar matahari kelihatan mengkilap seperti kristal, menurut warga setempat pasir putih ini biasanya digunakan untuk membersihkan kapal, campuran semen, dan lapisan permukaan lapangan futsal, namun sampai saat ini masih jarang yang menggunakan pasir putih ini untuk campuran beton. 


\section{METODOLOGI PENELITIAN}

\subsection{Skema Penelitian}

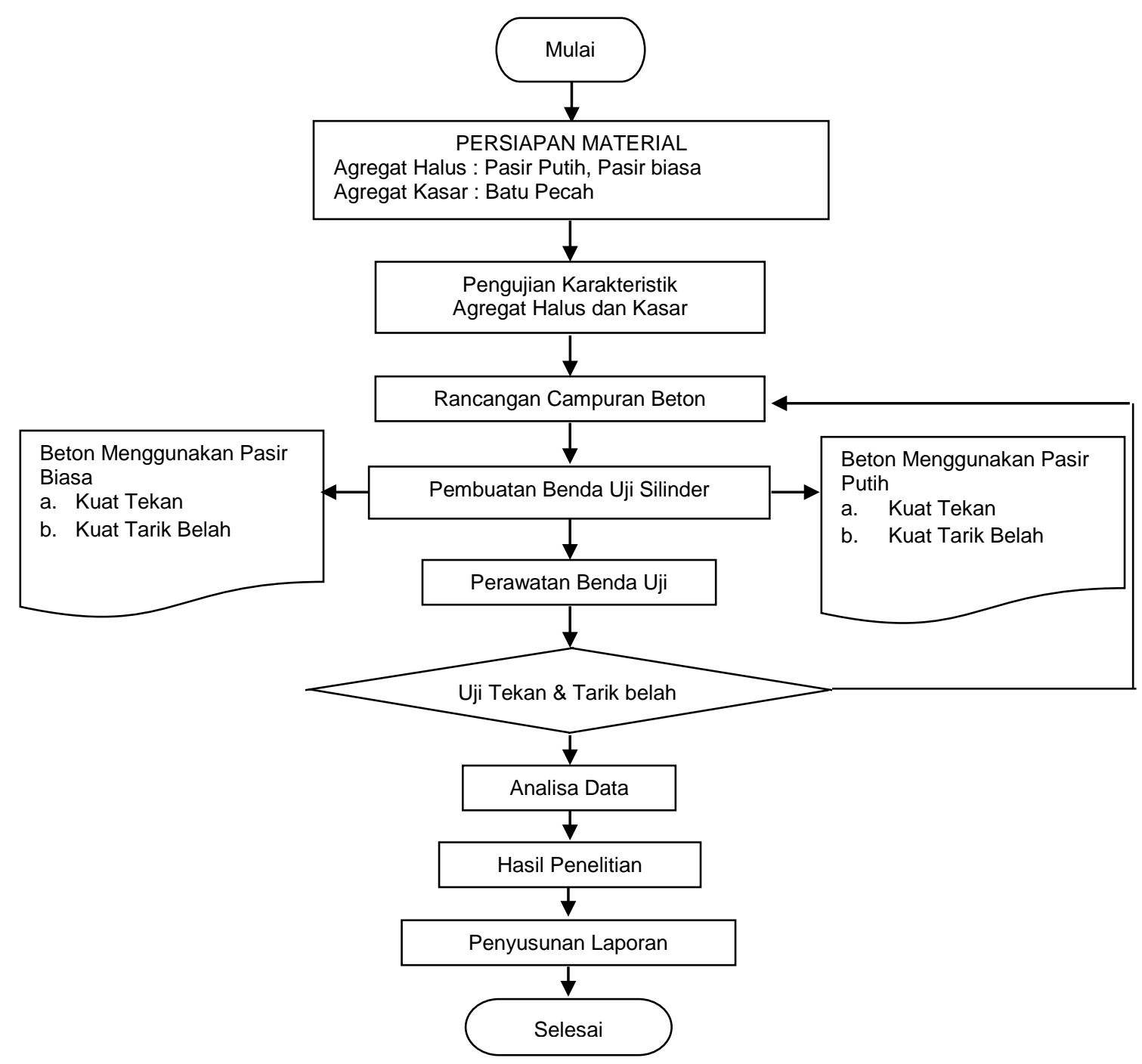

Gambar 3.1 Skema Penelitian

\subsection{Bahan yang digunakan}

a. Agregat halus ( pasir putih dan pasir biasa ) sumber material diambil dari dusun Kessi Pute Kecamatan Baranti Kabupaten Sidenreng Rappang dan sungai Lasape' Kabupaten Pinrang

b. Agregat kasar ( batu pecah ) yang biasa di peroleh dari pemasok bahan bangunan di Makassar

C. Semen portland Tipe I (Portland Cement) produksi Semen Tonasa

d. Air dari PDAM 


\subsection{Prosedur Penellitian}

Tahapan penelitian dilakukan sebagai berikut :

a. Melakukan pengujian sifat karakteristik agregat halus dan agregat kasar.

b. Merancang campuran beton dengan berdasarkan SNI 03-2834-1993 atau cara DOE untuk mendapatkan komposisi material penyusun beton untuk pasir putih dan pasir biasa

\section{HASIL PENELITIAN DAN PEMBAHASAN}

\subsection{Hasil Penelitian}

\subsubsection{Data Karakteristik Agregat}

Tabel 4.1 Hasil pemeriksaan karakteristik pasir putih

\begin{tabular}{|c|c|c|c|c|c||}
\hline No & Karakteristik & Spesifikasi & ASTM & Hasil & Keterangan \\
\hline \hline 1 & Kadar Air & $3 \%-5 \%$ & C556 & $0.080 \%$ & Tidak Memenuhi \\
\hline 2 & Kadar Lumpur & $0,2 \%-6 \%$ & C117 & $0,135 \%$ & $\begin{array}{c}\text { Tidak } \\
\text { Memenuhi }\end{array}$ \\
\hline 3 & Berat Volume & $1,4-1,9 \mathrm{~kg} / \mathrm{ltr}$ & $\mathrm{C} 29$ & $1,771 \mathrm{~kg} / \mathrm{ltr}$ & Memenuhi \\
\hline 4 & Berat Jenis SSD & $1,6-3,2$ & $\mathrm{C} 128$ & 2,606 & Memenuhi \\
\hline 5 & Absorbsi & $0,2-2 \%$ & $\mathrm{C} 128$ & $0,412 \%$ & Memenuhi \\
\hline 6 & Kadar Organik & $\begin{array}{c}\text { Lebih muda warna } \\
\text { pembanding }\end{array}$ & $\mathrm{C} 40$ & $\begin{array}{c}\text { Lebih muda warna } \\
\text { pembanding }\end{array}$ & Memenuhi \\
\hline 7 & $\begin{array}{c}\text { Modulus } \\
\text { Kehalusan }\end{array}$ & $2,2-3,1$ & $\mathrm{C} 128$ & 2,220 & Memenuhi \\
\hline \hline
\end{tabular}

Tabel 4.2 Hasil pemeriksaan karakteristik pasir biasa

\begin{tabular}{|c|c|c|c|c|c||}
\hline No & Karakteristik & Spesifikasi & ASTM & Hasil & Keterangan \\
\hline \hline 1 & Kadar Air & $3 \%-5 \%$ & C556 & $1,841 \%$ & $\begin{array}{c}\text { Tidak } \\
\text { Memenuhi }\end{array}$ \\
\hline 2 & Kadar Lumpur & $0,2 \%-6 \%$ & C117 & $1.300 \%$ & Memenuhi \\
\hline 3 & Berat Volume & $1,4-1,9 \mathrm{~kg} / \mathrm{ltr}$ & $\mathrm{C} 29$ & $1,488 \mathrm{~kg} / \mathrm{ltr}$ & Memenuhi \\
\hline 4 & Berat Jenis SSD & $1,6-3,2$ & $\mathrm{C} 128$ & 2,612 & Memenuhi \\
\hline 5 & Absorbsi & $0,2-2 \%$ & C128 & $1.595 \%$ & Memenuhi \\
\hline 6 & Kadar Organik & $\begin{array}{c}\text { Lebih muda warna } \\
\text { pembanding }\end{array}$ & C40 & $\begin{array}{c}\text { Lebih muda warna } \\
\text { pembanding }\end{array}$ & Memenuhi \\
\hline 7 & $\begin{array}{c}\text { Modulus } \\
\text { Kehalusan }\end{array}$ & $2,2-3,1$ & C128 & 1.864 & $\begin{array}{c}\text { Tidak } \\
\text { Memenuhi }\end{array}$ \\
\hline \hline
\end{tabular}

Tabel 4.3 Hasil pemeriksaan karakteristik batu pecah

\begin{tabular}{|c|c|c|c|c|c||}
\hline \hline No & Karakteristik & Spesifikasi & ASTM & Hasil & Keterangan \\
\hline \hline 1 & Kadar Air & $0,5 \%-2 \%$ & C556 & $0.827 \%$ & Memenuhi \\
\hline 2 & Kadar Lumpur & $0,2 \%-1 \%$ & C117 & $0.383 \%$ & Memenuhi \\
\hline 3 & Berat Volume & $1,6-1,9 \mathrm{~kg} / \mathrm{ltr}$ & C29 & $1,501 \mathrm{~kg} / \mathrm{ltr}$ & $\begin{array}{c}\text { Tidak } \\
\text { memenuhi }\end{array}$ \\
\hline
\end{tabular}




\begin{tabular}{||c|c|c|c|c|c||}
\hline 4 & Berat Jenis SSD & $1,6-3,2$ & C127 & 2,586 & Memenuhi \\
\hline 5 & Absorbsi & $0,2-4 \%$ & C127 & $1,082 \%$ & Memenuhi \\
\hline 6 & Keausan & $15 \%-50 \%$ & C131 & $25,5 \%$ & Memenuhi \\
\hline 7 & $\begin{array}{c}\text { Modulus } \\
\text { Kehalusan }\end{array}$ & $5,5-8,5$ & C140 & 6.720 & Memenuhi \\
\hline
\end{tabular}

\subsubsection{Rancangan Campuran Beton (Mix Design)}

\section{a. Rancangan campuran beton atau mix design untuk f'c 22,5 Mpa dengan menggunakan Pasir putih.}

Tabel 4.4 Formulir rancangan campuran beton f'c 22,5 Mpa untuk pasir putih

\begin{tabular}{|c|c|c|c|c|c|}
\hline No & \multicolumn{2}{|c|}{ Uraian } & Tabel/grafik/ perhitungan & \multicolumn{2}{|c|}{ Nilai } \\
\hline 1 & \multicolumn{2}{|c|}{ Kuat tekan disyaratkan (f'c) } & Ditetapkan & \multicolumn{2}{|c|}{$22,5 \mathrm{Mpa}$} \\
\hline 2 & \multicolumn{2}{|c|}{ Deviasi standar, s } & Diketahui/SNI & \multicolumn{2}{|l|}{$7 \mathrm{Mpa}$} \\
\hline 3 & \multicolumn{2}{|c|}{ Nilai tambah (margin), M } & Perhitungan ( terlampir ) & \multicolumn{2}{|c|}{$11,48 \mathrm{Mpa}$} \\
\hline 4 & \multicolumn{2}{|c|}{$\begin{array}{l}\text { Kekuatan rata-rata yang } \\
\text { Direncanakan, fcr }\end{array}$} & 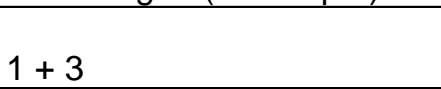 & \multicolumn{2}{|c|}{$33.98 \mathrm{Mpa}$} \\
\hline 5 & \multicolumn{2}{|l|}{ Jenis semen } & Ditetapkan & \multicolumn{2}{|c|}{ Semen PC type I } \\
\hline 6 & \multicolumn{2}{|c|}{$\begin{aligned} & \text { Jenis agregat :- } \text { kasar } \\
&- \text { Halus } \\
&\end{aligned}$} & $\begin{array}{l}\text { Ditetapkan } \\
\text { Ditetapkan }\end{array}$ & \multicolumn{2}{|c|}{$\begin{array}{l}\text { Batu pecah } \\
\text { Pasir Putih }\end{array}$} \\
\hline 7 & \multicolumn{2}{|c|}{ Faktor air semen bebas } & Tabel /grafik (terlampir) & \multicolumn{2}{|l|}{0.540} \\
\hline 8 & \multicolumn{2}{|c|}{ Faktor air semen maksimum } & Ditetapkan/SNI & \multicolumn{2}{|l|}{0.60} \\
\hline 9 & \multicolumn{2}{|l|}{ Slump } & Ditetapkan/SNI & \multicolumn{2}{|c|}{$75-150 \mathrm{~mm}$} \\
\hline 10 & \multicolumn{2}{|c|}{ Ukuran agregat maksimum } & Ditetapkan & \multicolumn{2}{|l|}{$20 \mathrm{~mm}$} \\
\hline 11 & \multicolumn{2}{|c|}{ Kadar air bebas } & Perhitungan & \multicolumn{2}{|c|}{$205 \mathrm{Kg} / \mathrm{m} 3$} \\
\hline 12 & \multicolumn{2}{|l|}{ Kadar semen } & $11 ; 7$ & \multicolumn{2}{|c|}{$380 \mathrm{Kg} / \mathrm{m} 3$} \\
\hline 13 & \multicolumn{2}{|c|}{ Kadar semen minimum } & Ditetapkan/SNI & \multicolumn{2}{|c|}{$275 \mathrm{~kg} / \mathrm{m3}$} \\
\hline 14 & \multicolumn{2}{|c|}{ Proporsi agregat halus } & Perhitungan & \multicolumn{2}{|l|}{$30 \%$} \\
\hline 15 & \multicolumn{2}{|c|}{ Proporsi agregat kasar } & Perhitungan & \multicolumn{2}{|l|}{$70 \%$} \\
\hline 16 & \multicolumn{2}{|c|}{ Berat jenis agregat halus } & Perhitungan & \multicolumn{2}{|l|}{2,606} \\
\hline 17 & Berat jenis ag & sar & Perhitungan & 2,590 & \\
\hline 18 & Berat jenis ag & bungan & $(14 \times 16)+(15 \times 17)$ & 2,592 & \\
\hline 19 & Berat volume & egar & Grafik ( terlampir ) & $2330 \mathrm{kc}$ & \\
\hline 20 & Kadar agrega & & $19-11-12$ & $1745 \mathrm{kc}$ & \\
\hline 21 & Kadar agrega & & $14 \times 20$ & $524 \mathrm{~kg} /$ & \\
\hline 22 & Kadar agrega & & 2021 & $1222 \mathrm{~kg} /$ & \\
\hline Ban & aknya bahan & Semen & Air & $\begin{array}{l}\text { Agregat } \\
\text { Kasar }\end{array}$ & $\begin{array}{l}\text { Agregat } \\
\text { Halus }\end{array}$ \\
\hline$(\mathrm{Kg}$ & m3 ) & 380 & 205 & 1222 & 524 \\
\hline
\end{tabular}

b. Rancangan campuran beton atau mix design untuk f'c 22,5 MPa dengan menggunakan pasir biasa

Tabel 4.5 Formulir rancangan campuran beton f'c 22,5 Mpa untuk pasir biasa

\begin{tabular}{||c|l|l|l||}
\hline No & \multicolumn{1}{|c|}{ Uraian } & \multicolumn{1}{|c||}{ Tabel/grafik/ perhitungan } & \multicolumn{1}{c||}{ Nilai } \\
\hline 1 & Kuat tekan disyaratkan (f'c) & Ditetapkan & $22,5 \mathrm{Mpa}$ \\
\hline 2 & Deviasi standar, S & Diketahui/SNI & $7 \mathrm{Mpa}$ \\
\hline 3 & Nilai tambah (margin), M & Perhitungan ( terlampir ) & $11,48 \mathrm{Mpa}$ \\
\hline
\end{tabular}




\begin{tabular}{|c|c|c|c|c|c|}
\hline 4 & \multicolumn{2}{|c|}{$\begin{array}{l}\text { Kekuatan rata-rata yang } \\
\text { Direncanakan, fcr }\end{array}$} & $1+3$ & \multicolumn{2}{|c|}{$33,98 \mathrm{Mpa}$} \\
\hline 5 & \multicolumn{2}{|c|}{ Jenis semen } & Ditetapkan & \multicolumn{2}{|c|}{ Semen PC type I } \\
\hline 6 & \multicolumn{2}{|c|}{$\begin{array}{r}\text { Jenis agregat :- } \begin{array}{r}\text { kasar } \\
\text { Halus }\end{array} \\
\end{array}$} & $\begin{array}{l}\text { Ditetapkan } \\
\text { Ditetapkan }\end{array}$ & \multicolumn{2}{|c|}{$\begin{array}{l}\text { Batu pecah } \\
\text { Pasir biasa }\end{array}$} \\
\hline 7 & \multicolumn{2}{|c|}{ Faktor air semen bebas } & $\begin{array}{l}\text { Tabel/grafik } \\
\text { (terlampir) }\end{array}$ & \multicolumn{2}{|l|}{0.540} \\
\hline 8 & \multicolumn{2}{|c|}{ Faktor air semen maksimum } & Ditetapkan/SNI & \multicolumn{2}{|l|}{0.60} \\
\hline 9 & \multicolumn{2}{|l|}{ Slump } & Ditetapkan/SNI & \multicolumn{2}{|c|}{$75-150 \mathrm{~mm}$} \\
\hline 10 & \multicolumn{2}{|c|}{ Ukuran agregat maksimum } & Ditetapkan & \multicolumn{2}{|l|}{$20 \mathrm{~mm}$} \\
\hline 11 & \multicolumn{2}{|c|}{ Kadar air bebas } & Perhitungan & \multicolumn{2}{|c|}{$205 \mathrm{Kg} / \mathrm{m} 3$} \\
\hline 12 & \multicolumn{2}{|c|}{ Kadar semen } & $11 ; 7$ & \multicolumn{2}{|c|}{$380 \mathrm{Kg} / \mathrm{m3}$} \\
\hline 13 & \multicolumn{2}{|c|}{ Kadar semen minimum } & Ditetapkan/SNI & \multicolumn{2}{|c|}{$275 \mathrm{~kg} / \mathrm{m} 3$} \\
\hline 14 & \multicolumn{2}{|c|}{ Proporsi agregat halus } & Perhitungan & \multicolumn{2}{|l|}{$27 \%$} \\
\hline 15 & \multicolumn{2}{|c|}{ Proporsi agregat kasar } & Perhitungan & \multicolumn{2}{|l|}{$73 \%$} \\
\hline 16 & \multicolumn{2}{|c|}{ Berat jenis agregat halus } & Perhitungan & \multicolumn{2}{|l|}{2,612} \\
\hline 17 & \multicolumn{2}{|c|}{ Berat jenis agregat kasar } & Perhitungan & \multicolumn{2}{|l|}{2,590} \\
\hline 18 & \multicolumn{2}{|c|}{ Berat jenis agregat gabungan } & $(14 \times 16)+(15 \times 17)$ & \multicolumn{2}{|l|}{2,593} \\
\hline 19 & \multicolumn{2}{|c|}{ Berat volume beton segar } & Grafik ( terlampir ) & \multicolumn{2}{|c|}{$2330 \mathrm{~kg} / \mathrm{m} 3$} \\
\hline 20 & \multicolumn{2}{|c|}{ Kadar agregat gabungan } & $19-11-12$ & \multicolumn{2}{|c|}{$1745 \mathrm{~kg} / \mathrm{m} 3$} \\
\hline 21 & \multicolumn{2}{|c|}{ Kadar agregat halus } & $14 \times 20$ & \multicolumn{2}{|c|}{$471 \mathrm{~kg} / \mathrm{m} 3$} \\
\hline 22 & Kadar agreg & & 2021 & $1274 \mathrm{~kg} / \mathrm{l}$ & \\
\hline Bar & aknya bahan & Semen & Air & $\begin{array}{c}\text { Agregat } \\
\text { Kasar }\end{array}$ & $\begin{array}{c}\text { Agregat } \\
\text { Halus }\end{array}$ \\
\hline$(\mathrm{Kg}$ & m3 ) & 380 & 205 & 1274 & 471 \\
\hline
\end{tabular}

\subsubsection{Uji Kuat Tekan beton}

\section{a. Hasil uji kuat tekan beton pasir putih}

Berdasarkan hasil uji kuat tekan beton, diperoleh hasil untuk beton pasir putih yang ditunjukkan pada Tabel 4.6 di bawah ini.

Tabel 4.6 Hasil uji kuat tekan untuk beton pasir putih

\begin{tabular}{|c|c|c|}
\hline No & Kode & $\begin{array}{c}\text { f'c 28 } \\
\text { (Mpa })\end{array}$ \\
\hline \hline 1 & PP1 & 28.31 \\
\hline 2 & PP2 & 37.93 \\
\hline 3 & PP3 & 35.67 \\
\hline 4 & PP4 & 36.52 \\
\hline 5 & PP5 & 36.52 \\
\hline 6 & PP6 & 29.44 \\
\hline 7 & PP7 & 26.89 \\
\hline 8 & PP8 & 32.55 \\
\hline 9 & PP9 & 30.01 \\
\hline 10 & PP10 & 30.01 \\
\hline 11 & PP11 & 27.46 \\
\hline 12 & PP12 & 32.84 \\
\hline 13 & PP13 & 38.22 \\
\hline 14 & PP14 & 28.87 \\
\hline 15 & PP15 & 32.27 \\
\hline 16 & PP16 & 27.74 \\
\hline
\end{tabular}




\begin{tabular}{||c|c|c||}
\hline 17 & PP17 & 33.97 \\
\hline 18 & PP18 & 23.21 \\
\hline 19 & PP19 & 37.93 \\
\hline 20 & PP20 & 25.19 \\
\hline \multicolumn{2}{|c|}{ Jumlah } & 631.56 \\
\hline \multicolumn{2}{|c|}{ Rata - rata (f'cr) } & 31.58 \\
\hline
\end{tabular}

Dari hasil pengujian kuat tekan beton menggunakan pasir putih, dapat dihitung tingkat mutu pelaksanaan pembuatan beton yang telah dilakukan, sehingga diperoleh nilai kuat tekan beton ( f'c ).

$$
\begin{aligned}
S & =\sqrt{\frac{\sum_{1}^{n}\left(f^{\prime} c 28-f^{\prime} c r\right)^{2}}{n-1}} \\
S & =\sqrt{\frac{390,99}{19}} \\
S & =4,54 \mathrm{Mpa} \\
f^{\prime} \mathrm{C} & =f^{\prime} \mathrm{cr}-1,64 \cdot \mathrm{S} \\
& =31,58-1,64 \cdot 4,54 \\
& =24.19 \mathrm{Mpa}
\end{aligned}
$$

b. Hasil Uji Kuat Tekan Beton Pasir Biasa

Berdasarkan hasil uji kuat tekan beton diperoleh hasil untuk beton pasir biasa yang ditunjukkan pada Tabel 4.7

Tabel 4.7 Hasil uji kuat tekan untuk beton pasir biasa

\begin{tabular}{|c|c|c||}
\hline No & Kode & $\begin{array}{c}\text { f'c 28 } \\
\text { (Mpa })\end{array}$ \\
\hline \hline 1 & PB1 & 24.35 \\
\hline 2 & PB2 & 32.55 \\
\hline 3 & PB3 & 31.71 \\
\hline 4 & PB4 & 26.61 \\
\hline 5 & PB5 & 28.87 \\
\hline 6 & PB6 & 28.87 \\
\hline 7 & PB7 & 24.06 \\
\hline 8 & PB8 & 27.18 \\
\hline 9 & PB9 & 27.18 \\
\hline 10 & PB10 & 26.33 \\
\hline 11 & PB11 & 25.48 \\
\hline 12 & PB12 & 26.89 \\
\hline 13 & PB13 & 22.65 \\
\hline 14 & PB14 & 26.33 \\
\hline
\end{tabular}




\begin{tabular}{|c|c|c|}
\hline 15 & PB15 & 27.18 \\
\hline 16 & PB16 & 26.61 \\
\hline 17 & PB17 & 24.06 \\
\hline 18 & PB18 & 26.61 \\
\hline 19 & PB19 & 24.63 \\
\hline 20 & PB20 & 24.06 \\
\hline \multicolumn{2}{|c|}{ Jumlah } & 532.20 \\
\hline \multicolumn{2}{|c|}{ Rata - rata ( fcr ) } \\
\hline
\end{tabular}

Dari hasil pengujian kuat tekan beton menggunakan pasir biasa, dapat dihitung tingkat mutu pelaksanaan pembuatan beton yang telah dilakukan, sehingga diperoleh nilai kuat tekan beton ( f'c ).

$S=\sqrt{\frac{\sum_{1}^{n}\left(f^{\prime} c 28-f^{\prime} c r\right)^{2}}{n-1}}$

$S=\sqrt{\frac{118,28}{19}}$

$\mathrm{S}=2,50 \mathrm{Mpa}$

$f^{\prime} c=f^{\prime} c r-1,64 . S$

$f^{\prime} c=26,61-1,64 \cdot 2,50$

$\mathrm{f}^{\prime} \mathrm{C}=22,52 \mathrm{Mpa}$

Dari hasil pengujian kuat tekan beton dapat dibuat grafik perbandingan kuat tekan beton pasir putih dengan pasir biasa untuk masing - masing benda uji, seperti pada grafik 4.1

Grafik 4.1 Perbandingan kuat tekan beton untuk masing - masing benda uji (f'c 28)

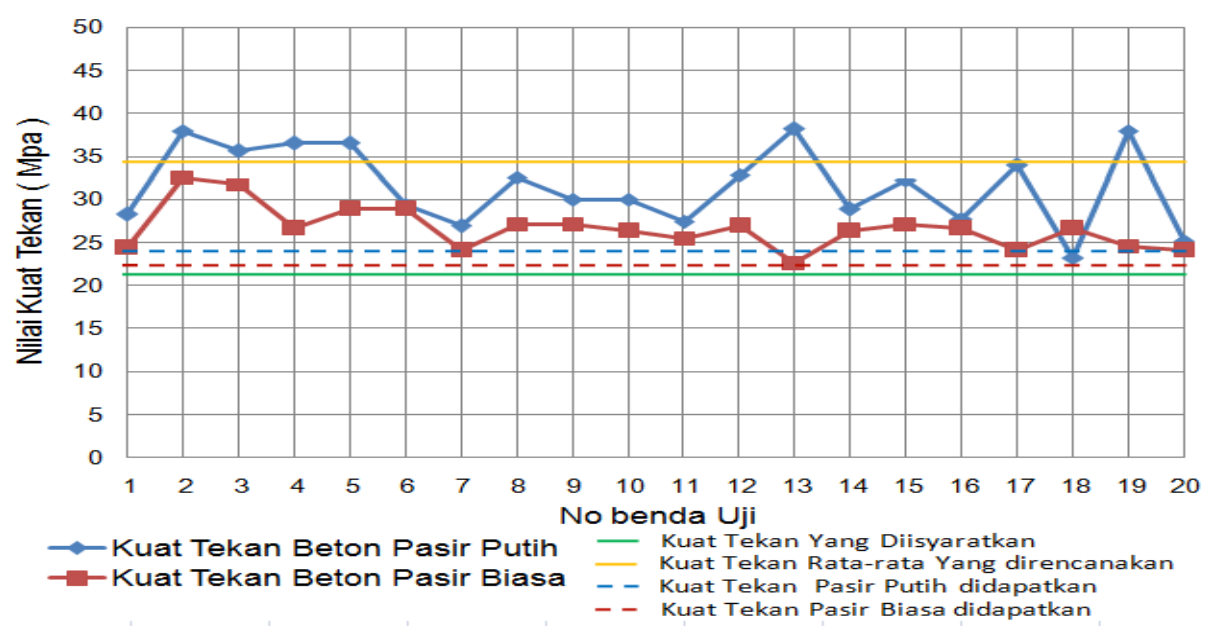


Dari Grafik 4.1 dapat dlihat kuat tekan untuk masing-masing benda uji dimana didapatkan satu buah benda uji pasir putih yang berada dibawah kuat tekan dari benda uji yang lainnya hal ini dipengaruhi oleh suhu tempat perawatan benda uji yang dibuat berbeda sebagian berada diluar ruangan, sebagian berada dalam ruangan, seperti uang dijelaskan oleh Samekto dan Rahmadiyanto (2001:43) untuk “ kecepatan bertambahnya kekuatan beton tersebut sangat dipengaruhi oleh factor air semen dan suhu perawatannya" hal ini masih sesuai dengan syarat factor kegagalan maksimal $5 \%$ dari total benda uji

\subsubsection{Uji Kuat Tarik Belah Beton}

a. Hasil uji kuat tarik belah beton pasir putih

Berdasarkan hasil uji kuat tarik belah beton, diperoleh hasil untuk beton pasir putih seperti yang ditunjukkan pada Tabel 4.8 di bawah ini.

Tabel 4.8 Hasil uji kuat tarik belah untuk beton pasir putih

\begin{tabular}{||c|c|c||}
\hline No & Kode & $\begin{array}{c}\text { Kuat Tarik Belah } \\
(\mathrm{MPa})\end{array}$ \\
\hline \hline 1 & PP I & 3.54 \\
\hline 2 & PP II & 2.97 \\
\hline 3 & PP III & 3.33 \\
\hline \multicolumn{2}{|c|}{ Kuat Tarik Belah Beton Rata - rata } & 3.28 \\
\hline
\end{tabular}

b. Hasil uji kuat tarik belah beton pasir biasa

Berdasarkan hasil uji kuat tarik belah beton, diperoleh hasil untuk beton pasir biasa seperti yang ditunjukkan pada Tabel 4.9.

Tabel 4.9 Hasil uji kuat tarik belah untuk beton pasir biasa

\begin{tabular}{|c|c|c||}
\hline No & Kode & $\begin{array}{c}\text { Kuat Tarik Belah } \\
(\mathrm{MPa})\end{array}$ \\
\hline \hline 1 & PB I & 3.18 \\
\hline 2 & PB II & 3.33 \\
\hline 3 & PB III & 2.83 \\
\hline \multicolumn{2}{|c|}{ Kuat Tarik Belah Beton Rata - rata } & 3.11 \\
\hline
\end{tabular}


Dari hasil pengujian kuat tarik belah beton dapat dibuat grafik perbandingan kuat tarik belah beton pasir putih dengan pasir biasa untuk masing - masing benda uji, seperti pada grafik 4.2

Grafik 4.2 Perbandingan kuat tarik belah beton untuk masing - masing benda uji

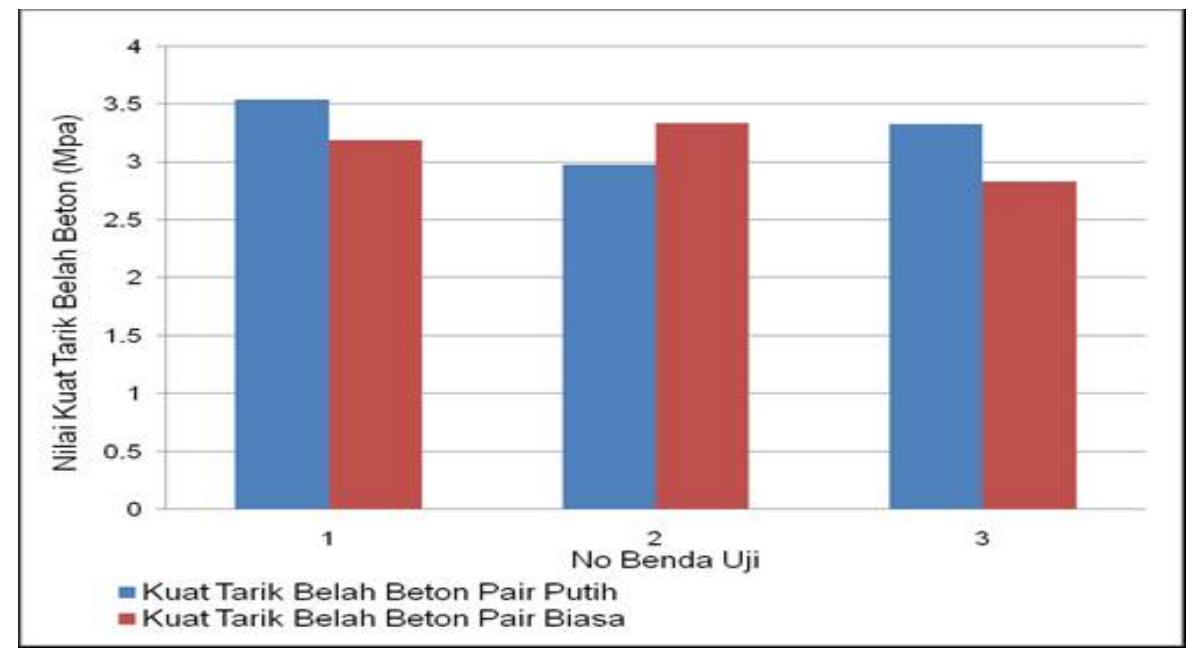

\subsection{Pembahasan}

Dari hasil pengujian laboratorium yang dilakukan, mulai dari pemeriksaan karakteristik agregat seperti yang telihat pada tabel 4.1 sampai tabel 4.3 memperlihatkan karakteristik yang berbeda antara pasir putih dengan pasir biasa, dari pemeriksaan karakteristik tersebut terdapat beberapa pemeriksaan yang tidak memenuhi spesifikasi yaitu kadar air pasir putih ( 0,080 \%), kadar air pasir biasa ( 1,841 \%), kadar lumpur pasir putih ( 0,135\%), dan modulus kehalusan pasir biasa ( 1,864).

Untuk menghindari kelebihan atau kekurangan air, kadar air pasir putih dan pasir biasa yang rendah telah dilakukan koreksi terhadap kondisi kering permukaan, sehingga kadar air agregat yang digunakan dalam perencanaan campuran beton telah disesuaikan. Sementara kadar lumpur yang terkandung pada pasir putih yang rendah, dipengaruhi karena pada saat penambangan pasir putih terlebih dahulu dilakukan penyaringan untuk menghilangkan air dan lumpur yang terbawa bersama pasir sebelum dikumpulkan atau disimpan. Proses ini juga mempengaruhi kebersihan agregat pasir putih yang digunakan untuk campuran beton, 
karena kebersihan agregat juga akan sangat mempengaruhi dari mutu beton yang akan dibuat. Seperti yang dijelaskan oleh Samekto dan Rahmadiyanto ( 2001 : 21 ) "Lempung, lumpur, dan debu atau butiran butiran halus lainnya yang mungkin terdapat / menempel pada permukaan agregat, dapat mengganggu ikatan antara agregat dan pasta semennya ". Modulus kehalusan pasir biasa yang lebih rendah daripada pasir putih dipengaruhi karena pasir ini diperoleh langsung dari dasar sungai, yang pada umumnya berbutir halus dan bulat - bulat akibat proses gesekan.

Berdasarkan hasil uji kuat tekan dan uji tarik belah beton yang dilakukan, beton dengan menggunakan pasir putih diperoleh nilai kuat tekan beton ( $\left.f^{\prime} c\right)$ sebesar 24,19 Mpa dan untuk kuat tarik belah sebesar 3,28 Mpa . Dibandingkan dengan nilai kuat tekan menggunakan pasir putih, kuat tekan yang didapatkan dengan menggunakan pasir biasa lebih kecil, yaitu sebesar 22,52 Mpa dan untuk kuat tarik belah beton diperoleh 3,11 Mpa. *

Tabel 4.10 Persentase kuat tarik belah dan kuat tekan

\begin{tabular}{|c|c|c|c|}
\hline Uraian & $\begin{array}{c}\text { Kuat Tekan } \\
\text { Beton } \\
(\mathrm{Mpa})\end{array}$ & $\begin{array}{c}\text { Kuat Tarik } \\
\text { Rata - rata } \\
(\mathrm{Mpa})\end{array}$ & $\begin{array}{c}\text { Persentase } \\
(\%)\end{array}$ \\
\hline \hline $\begin{array}{c}\text { Beton dengan menggunakan } \\
\text { pasir putih }\end{array}$ & 24,19 & 3,28 & 13.6 \\
\hline $\begin{array}{c}\text { Beton dengan menggunakan } \\
\text { pasir biasa }\end{array}$ & 22,52 & 3,11 & 13.8 \\
\hline
\end{tabular}

Grafik 4.3 Diagram kuat tekan dan kuat tarik belah beton

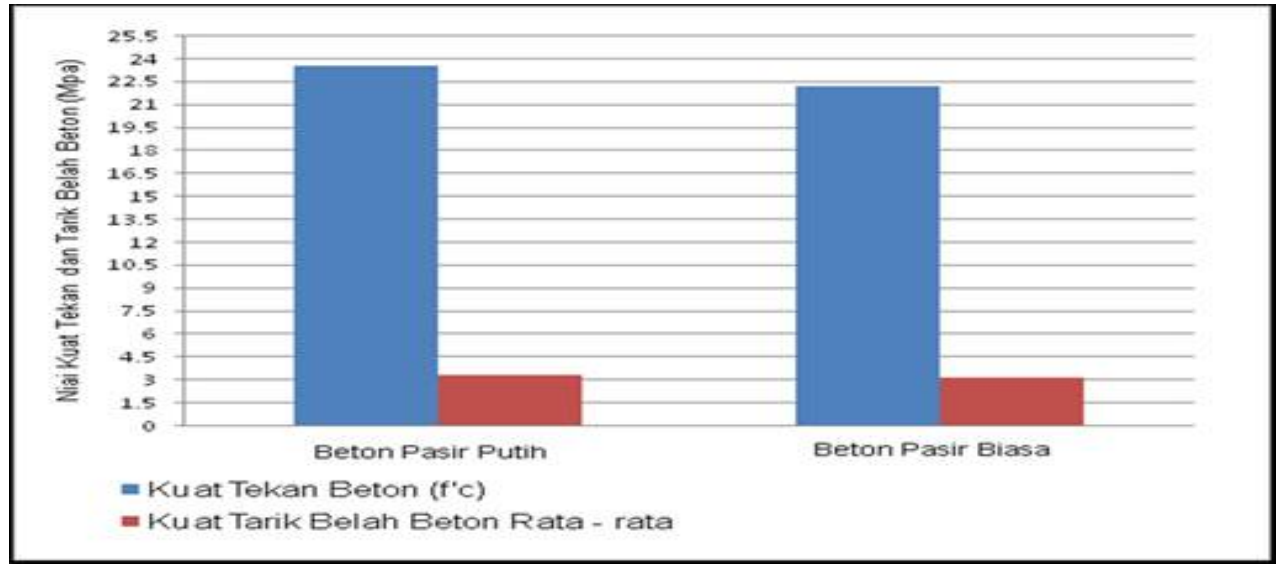


Persentase kuat tarik belah beton pasir putih adalah $13.6 \%$ terhadap kuat tekan beton pasir putih, sedangkan persentase kuat tarik belah beton pasir biasa adalah 13.8 \% terhadap kuat tekan beton pasir biasa. Kuat tarik belah beton sendiri berkisar antara 9 - $15 \%$ seperti yang dijelaskan oleh Dipohusodo ( 1999 ), Kuat tarik beton berkisar antara $9 \%$ - $15 \%$ dari kuat tekannya

Mutu beton atau nilai kuat tekan beton (f'c) menggunakan pasir putih sebesar 24.19 Mpa, sedangkan nilai kuat tekan beton (f'c) menggunakan pasir biasa sebesar 22,52 Mpa. Kuat tekan yang dihasilkan dengan menggunakan pasir biasa lebih kecil dibandingkan menggunakan pasir putih, hal ini dipengaruhi oleh agregat pasir biasa yang lebih halus sehingga kuat tekan yang dihasilkan lebih kecil dari kuat tekan pasir putih.

\section{KESIMPULAN}

Berdasarkan hasil penelitian dan analisis data yang telah kami lakukan maka dari pengujian karakteristik agregat, kuat tekan dan kuat tarik belah beton dapat ditarik beberapa kesimpulan bahwa:

1. Dari hasil pemeriksaan karakteristik diperoleh bahwa agregat pasir putih baik digunakan untuk campuran beton karena pada umumnya memenuhi syarat karakteristik agregat,

2. Dengan menggunakan agregat pasir putih nilai kuat tekan beton (f'c) diperoleh 24,19 Mpa, sedangkan untuk kuat tarik belah beton diperoleh 3,28 Mpa atau $13.6 \%$ dari kuat tekannya.

3. Dengan menggunakan agregat pasir biasa nilai kuat tekan beton (f'c) diperoleh 22,52 Mpa, sedangkan untuk kuat tarik belah beton diperoleh 3,11 Mpa atau $13.8 \%$ dari kuat tekannya.

4. Dibandingkan dengan nilai kuat tekan beton (f'c) menggunakan pasir putih dan pasir biasa, nilai kuat tekan beton menggunakan pasir putih lebih tinggi dibanding menggunakan pasir biasa, hal ini dipengaruhi oleh agregat pasir biasa lebih halus dari pada pasir putih, dan pasir biasa dari sungai Lasape' tidak dapat digunakan sebagai material 
pembuatan beton dan selisih kuat tekan pasir putih dengan pasir biasa sebesar 1,35 Mpa.

\section{DAFTAR PUSTAKA}

1. Amri, S, 2005. Teknologi Beton A- Z . John Hi - Tech Idetama, Jakarta.

2. ASTM, 1996. Annual Book of ASTM Standard Volume 04.02 Concrete and Aggregate. Easton M.D,USA.

3. Departemen Pekerjaan Umum, 2002. Tata Cara Pembuatan Rencana Campuran Beton Normal (SK-SNI T-15-1990-03). Yayasan LPMB,Bandung.

4. Departemen Pekerjaan Umum, 2005. Tata Cara Perhitungan Struktur Beton Untuk Bangunan Gedung (SK-SNI 03-28472002). Yayasan LPMB,Bandung.

5. Departemen Pekerjaan Umum, 1971. Peraturan Beton Bertulang Indonesia 1971. Yayasan LPMB,Bandung.

6. Dipohosudo, I, 1999. Struktur Beton Bertulang, Gramedia Pustaka Utama, Jakarta

7. Tjokrodimulyo, K. 2007. Teknologi Beton. Teknik Sipil dan Lingkungan Universitas Gadjah Mada, Yogyakarta.

8. Mulyono, T. 2004. Teknologi Beton. CV. Andi Offset, Yogyakarta.

9. Nugraha, P dan Antoni, 2007. Teknologi Beton, CV. Andi Offset, Yogyakarta.

10. Samekto, W dan Rahmadiyanto C,2001. Teknologi Bahan, Kanisius, Yogyakarta. 